
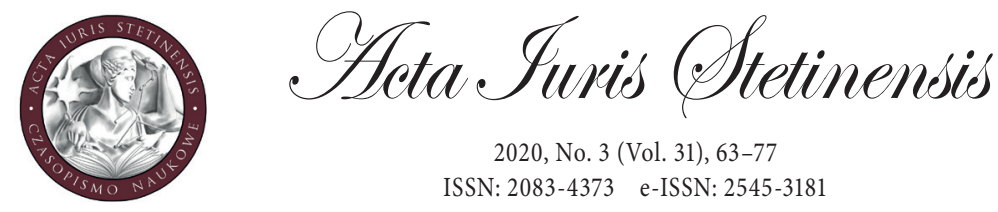

2020, No. 3 (Vol. 31), 63-77

ISSN: 2083-4373 e-ISSN: 2545-3181

DOI: 10.18276/ais.2020.31-04

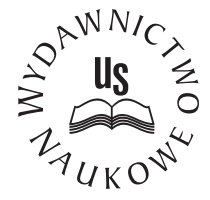

\title{
Aneta Paleczna
}

MA, Ph.D. student

University of Silesia in Katowice, Poland

Institute of Law

Trainee advocate at the District Bar Association in Katowice

e-mail: paleczna.aneta@gmail.com

ORCID ID: 0000-0001-7951-2006

\section{Suicide as an insurance accident}

\begin{abstract}
This paper constitutes an attempt at the analysis of provisions of the Civil Code regarding suicide in an insurance contract. The aim of the paper is to analyse the economic aspect of a suicidal death. Regardless of this analysis, a few aspects related to death by suicide in the insurance industry have been indicated. In this paper, the author also analysed the German legal system conception. Therefore, the method of examining applicable laws and the legalcomparative methods have been used herein. The main conclusion drawn up on the grounds of the conducted research is that strict legal regulations are not compatible with suicide as a complex psychological and social process.
\end{abstract}

Keywords: suicide, insured, insurance accident, insurance contract, insurance benefit

\section{Introduction}

Suicide, being voluntary resignation from life, has a social dimension, usually considered on a psychological and mental level. Furthermore, a suicidal act constitutes 
an indicator of the state and level of social and personality integration. ${ }^{1}$ This issue covers three elements: the first is the desire to kill oneself (a component of masochism), the second is the will to kill somebody from one's own environment as a result of one's own death (a component of sadism) and the third is the longing for death. ${ }^{2}$ These elements allow an observation that a complexity of motives constitutes the grounds of the decision to commit suicide.

In the present period of strong and turbulent political, social and economic transformations (so-called: big change syndrome), the number of suicidal deaths is growing. In years of stability and a sense of security as well as integration to protect common values, the number of suicides drops. Although in Poland the number of suicides is relatively small, it is growing continuously. ${ }^{3}$

Therefore, in the face of dynamic economic changes, the issue of suicide deserves an in-depth analysis not only from the psychological, mental or formal-criminal but also the economic perspective. Usually, a person's death activates the insurer's obligation to pay a personal insurance benefit, whereas suicide is a special situation and depends on the will of the insured person.

Herein, the suicidal death will be analysed from the perspective of the insurance contract and its random character. Consideration thereof against an insurance event, the existence of which activates the insurer's obligation to pay insurance, is equally important. A detailed assessment will cover the issue of paying the benefit by the insurer in the case of the insured person's death and depression, which is an illness that often precedes suicide and is of significance on the grounds of an insurance contract and the policyholder's information obligations.

1 Czabański, A. and Mariański, J., Samobójstwo w ujęciu Marii Janosz, “Teologia i Moralność” 2018, No. 2(24), p. 225. See more: Durkheim, E., Samobójstwo. Studium z socjologii, translated by Wakar K., Warszawa 2006.

2 Manninger, K.A., Man against himself, New York, 1938, op. cit.: Hołyst, B., Wiktymologia, Warszawa 2000, p. 192.

3 Czabański, A. and Mariański, J., op. cit., p. 238. The act of self-annihilation is one of ten most frequent reasons of death in each country, and also one of three most often declared causes of death among young people (aged between 15 and 35 years old). See: Lebiedowicz, A., Samobójstwo w ujęciu wielopłaszczyznowym, "Wojskowy Przegląd Prawniczy" 2013, No. 3, http://www.npw. internetdsl.pl/Dokumenty/2013-3/2013-3-5.pdf, p. 2 (accessed 18.02.2020). The Report of Statistics Poland implies that in 2016 the Polish Police Headquarters noted 9,861 suicide attempts, of which 5,405 , thus, almost $55 \%$ of cases ended with death. Men committed 4,638 suicides ( $85.8 \%$ cases), and women -767 . Suicides were more often committed in cities and towns (56.1\%) than in the countryside (43.9\%), https://stat.goVol.pl/obszary-tematyczne/ludnosc/statystyka-przyczynzgonow/zamachy-samobojcze-w-2016-r-,5,1.html (accessed 1.02.2020). 


\section{Insurance event}

To begin with, a few comments should be made concerning the essence of the insurance contract with which the insurer undertakes to fulfil a specific benefit in the case of an accident provided for in the contract, whereas the policyholder undertakes to pay a premium (Article 805 par. 1 of the Civil Code). ${ }^{4}$ At this point, the legislator distinguishes two types of insurance performances: compensation for a damage caused as a result of the accident provided for in the contract (in the case of a property insurance) and an amount of money, annuity or other performance in case the accident provided for in the contract happens in the insured person's life (in the case of personal insurance). Herein, one should focus on the latter.

The essence of insurance consists in persons who want to ensure compensation for damage resulting from a fortuitous event paying premiums to a fund from which in the case of such an event they later receive the performance. ${ }^{5}$ The aim of insurance is to provide the policyholder with insurance protection. ${ }^{6}$ The insurance contract is a consensual, ${ }^{7}$ paid, bilaterally binding and mutual agreement that also allows an insurance contract to be concluded with a reservation of a condition ${ }^{8}$ or a period of time.

In the literature there is an opinion, in compliance with which parties can agree that the contract is concluded only upon the policyholder's payment of a premium or at a time after this fact, at which point the consensual contract (solo consensu) becomes a real contract. Supporters of this opinion argue that such a transformation is possible only on the grounds of the principle of freedom of contracts (Article $353^{1}$ of the Civil Code) and is quite often used within the General Insurance

4 Act of 23 April 1964 - the Civil Code, Dz.U. (Journal of Laws) of 1964, no. 16 item 93 as amended.

5 Dubis, W., in: Gniewek, E. and Machnikowski, P. (eds.), Kodeks cywilny. Komentarz, Legalis 2019, par. No. 1.

6 Judgement of the Administrative Court in Krakow of 12 July 2018, I ACa 1595/17, Legalis No. 1865480.

7 An agreement is, in principle, concluded by submitting a unanimous declaration of will by the parties, effectiveness thereof does not require drawing up an agreement in writing. See: Judgement of the District Court in Wrocław of 29 June 2015, II Ca 800/15, Portal Orzeczeń Sądów Powszechnych, http://orzeczenia.wroclaw.so.goVol.pl/content/\$N/155025000001003 _II_Ca_000800_2015_Uz_2015-07-30_001 (accessed 20.02.2020).

8 A condition can be resolutive or precedent. In the factual circumstances of the case in which judgement of the Regional Court for Łódź-Widzew of 10 August 2016 was given, the defendant did not pay the insurance contribution and thus, the condition precedent, which obliged the insurer to provide the defendant with insurance cover, was not fulfilled (Article 89 of the Civil Code). See: judgement of the Regional Court for Łódź-Widzew of 10 August 2016, VIII C 3261/15, Legalis No. 2083866. 
Conditions. ${ }^{9}$ This position has been criticised due to the fact that the provisions of the Civil Code do not condition the effectiveness of an insurance contract's conclusion on premises other than the submission of parties' consistent declarations of will. Moreover, payment of the premium is important in the context of establishing the insurer's liability, but it does not constitute the condition of this contract's conclusion. ${ }^{10}$

The payment character of the contract is demonstrated in the policyholder's obligation to pay a premium to the insurer. The premium is the main payment paid by the policyholder to the insurer in exchange for insurance protection provided by the latter. ${ }^{11}$ Upon payment of the premium, the policyholder expects the insurer to pay a specific amount in the case of an insurance event resulting in the insurer's liability. ${ }^{12}$ It is calculated for the whole period of time for which the insurance contract has been concluded and the amount thereof is defined by the insurer, who leaves the decision on concluding the insurance contract to the policyholder (Article 813 of the Civil Code)..$^{13}$ The amount of the life insurance premium depends on a series of insurance risk factors, such as: age, gender, height and weight, alcohol or nicotine consumption, blood pressure, organ diseases, family circumstances, profession,

9 Kasprzyk, R., Glosa do wyroku SA w Łodzi z 14 marca 1996 r., I ACr 62/96, "Palestra” 1997, No. 3-4, p. 264.

10 Tadla, A., Umowa ubezpieczenia na życie, Warszawa 2000, p. 55; Szczepańska, M., Ubezpieczenie na życie z ubezpieczeniowym funduszem kapitałowym, Warszawa 2011, p. 80.

11 Fras, M., in: Habdas, M. and Fras, M. (eds.), Kodeks cywilny. Komentarz. Tom V. Zobowiązania. Część szczególna (art. 765 - 92116), Warszawa 2019, p. 191.

12 Judgement of the Supreme Court of 7 February 2001, V CKN 199/00, Legalis No. 291992. The subject matter of the amount of the premiums subject to reimbursement in case of terminating the insurance relationship was discussed in judicial decisions numerous times. The Supreme Court in Warszawa, in its judgement of 16 December 2011 adjudicated a general principle that stipulates that, if a legislator provides for the obligation to reimburse the premiums for the period of unused insurance cover, even if the insurance contract is terminated due to reasons not attributable to the parties' will, it cannot be stated that the legislator simultaneously allows contractual exclusion of such an obligation in case such a relationship's termination is a result of a decision made by one of the parties. See: judgment of the Administrative Court in Warszawa of 16 December 2011, VI ACa 1269/11, Legalis No. 532605. Whereas, the Supreme Court in its judgement of 9 September 2015, while analysing the amount of the premiums subject to reimbursement, adopted that it should be calculated according to a proportion, in which the period of unused insurance cover remains with regard to the whole period, in which the insurer's liability was originally to last. See: judgment of the Supreme Court of 9 September 2015, III SK 40/14, Legalis No. 1352544.

13 The premiums should ensure performance of all obligations under the insurance contract and cover costs of performing insurance activity by the insurer. See: Gawlik, Z., in: Kidyba, A. (ed.), Kodeks cywilny. Komentarz, Tom III, Warszawa 2014, p. 1035. 
and the way of spending leisure time. ${ }^{14}$ Risk is a component of several factors such as peril, uncertainty, probability and possibility, whereas the risk assessment system has been based on the field of clinical medicine, insurance medicine and insurance statistics. ${ }^{15}$ In such cases, the premium may increase by an additional coefficient. It will be a substandard insurance for risk higher than average. These circumstances are of great importance in chronic diseases including depression, which has been discussed more in the further part of the paper.

The insurance contract has a character of a bilateral obligation, since each party is obliged to provide a specific performance to the other party. The insurer is obliged to provide the insurance protection whereas the policyholder is to pay the premiums. However, from the perspective of the issue discussed herein, the randomness of the insurance contract is of key significance.

The obligation to provide the insurance performance is activated with the existence of the insurance event, therefore of an uncertain event. This, in turn, indicates the random character of the contract.

In the contents of Article 3 par. 1 point 57 of the Act on insurance and reinsurance activity (hereinafter: the Act on insurance and reinsurance activity) ${ }^{16}$ the legislator proposed a legal definition of a random event, in compliance with which it is a future and uncertain event, independent of the policyholder's or insured person's will, existence of which results in a detriment to the personal or property sphere, or an increase in property needs of a person covered with insurance. An insurance accident, provided that it is an uncertain event, ${ }^{17}$ does not always take the form of a future event. An insurance accident can be defined in a causal form, by indicating specific consequences of certain events, or in a non-causal form.

This accident should be specified in the contents of the contract. However, only the interpretation of the insurance contract together with its integral part, that is, the General Insurance Conditions, with the consideration of the rules stipulated in Article 65 par. 2 of the Civil Code, will allow proper identification of the event covered with the insurance contract.

14 Guzel-Szczepiórkowska, Z. and Visan, J., Ocena ryzyka w ubezpieczeniach życiowych, in: Doan, O. (ed.), Ubezpieczenia życiowe, Warszawa 1995, p. 121.

15 Puto, M., Wykluczenie $z$ ubezpieczenia na życie osób dotkniętych określonymi chorobami przewlektymi, "Wiadomości Ubezpieczeniowe" 2014, No. 2, p. 16.

16 Act of 11 September 2015 on insurance and reinsurance activity, Dz.U. (Journal of Laws) of 2015, item 1844 as amended.

17 In the literature it is indicated that an insurance accident, which has already happened, should not lose the characteristics of uncertainty. See: Kondek, J.M., in: Osajda, K. (ed.), Kodeks cywilny. Komentarz, Legalis 2020. 
While referring to the definition of an insurance event in any life insurance contract, in compliance with the established line of judicial decisions it is assumed that it can be freely stipulated pursuant to Article $353^{1}$ of the Civil Code. ${ }^{18}$ Provisions of Article 65 par. 1 and 2 of the Civil Code applied in the interpretation of the insurance contract imply that while translating declarations of will, not only the wording of the contract, but also the circumstances of making such declarations, the rules of social interaction and established customs should be taken into account, and the common intention of the parties and the objective of the agreement should also be examined (the combined interpretation). The content of the insurance contractual relationship is also determined by the provisions of the contractual template in the form of the General Insurance Conditions. Furthermore, since the insurer defined the contents of the General Insurance Conditions and the disputable provision excludes the insurer's liability, any ambiguities should be interpreted in a narrowing manner so that the insured person is covered. ${ }^{19}$

The estimates allowing assessment of the probability of existence of the specific event are of no importance with regard to the random character of the contract. Currently, in fact, the activity of insurers comes down to the diligent, possibly detailed estimation of the risk of the existence of the event with the use of scientific methods and mathematical rules. This activity allows assessment of the level of the insured risk. Thus, one may have an impression that the insurance contract loses its random character, since the existence of the insurance event does not constitute an uncertain event (macro scale); however, from the perspective of a specific legal relationship, it is never certain whether the insurance accident happens (micro scale). In fact, randomness constitutes the criterion of the contractual relationship's assessment and not the insurer's activity. ${ }^{20}$

It should be noted that the fundamental performance from the insurer in the form of providing insurance cover is executed irrespective of the existence of the insurance accident. Only the performance of this cover by payment of the performance depends on the existence of the insurance accident. Therefore, the insurance accident does not constitute a condition as an element of the contents of the legal

18 Judgement of the Administrative Court in Warszawa of 25 April 2019, I ACa 629/18, Legalis No. 2121870. Since the insurer phrased the contents of the General Insurance Conditions, and the questionable provision excludes the insurer's liability, any ambiguities should be construed in a narrowing manner in order to protect the insured. See: judgement of the Administrative Court in Warszawa of 3 April 2019, I ACa 53/18, Legalis No. 2122440.

19 Judgement of the Administrative Court in Warszawa of 3 April 2019, I ACa 53/18, Legalis No. 2122440.

20 Krajewski, M., Umowa ubezpieczenia. Art. 805 - 834 KC. Komentarz, Legalis 2016, par. 11. 
activity, since it has no impact on the existence of the insurance contract. Nevertheless, due to its meaning in the insurance contract, the assessment of suicide as the insurance event requires a diligent analysis.

\section{Suicide}

Suicide constitutes a special situation dependent on the will of the person who decides to die. With regard to the conscious decision aimed at committing suicide, this event loses the element of randomness. Therefore, the suicidal death of the insured person (the policyholder, in the case of contracts on a third party's account the insured) cannot be deemed as a random event and thus, the insurance accident. This particular reason of death, with fulfilment of relevant conditions, constitutes a negative premise for a monetary payment.

In compliance with the content of Article 833 of the Civil Code, if the insured person commits suicide 2 years after the day of concluding the insurance contract, the insurer will be obliged to perform to their benefit. It means that the criterion for determining payment of the performance is the period of time that passed between the date of the insurance contract's conclusion and the suicidal death, whereas the 2 year period of time can be shortened under a contract or the General Insurance Conditions to the period not shorter than 6 months (Article 833 of the Civil Code in fine $)^{21}$

At this point, it is worth underlining that the German legislator excludes the insurer's performance obligation where suicide is committed within 3 years as of conclusion of the insurance contract, whereas, this period can be modified by the parties to the contract. ${ }^{22}$

While attempting to define the concept of suicide from the perspective of the disposition of Article 833 of the Civil Code, it happens when the insured dies as a result of a premeditated and intentional action taken in order to end one's life. Therefore, death resulting from risky or even reckless activities of the insured that were not aimed at taking their own life, even if the person was aware of the threat to their life when they took such actions, is not a suicidal death. ${ }^{23}$ As indicated in

21 Before the amendment of Article 833 of the Civil Code by the Act of 13 April 2007, shortening the 3 -year term was common practice adopted by insurers. See: Fras, M., in: Habdas, M. and Fras, M., (eds.), op. cit., p. 391.

22 Section 161, Insurance Contract Act, Federal Law Gazette I page 2631, as amended, https://germanlawarchive.iuscomp.org/?p=861\#164 (accessed 1.02.2020).

23 Judgement of the District Court in Warszawa of 21 December 2016, IV C 508/14, LEX No. 2300638. 
the literature, a suicidal activity requires the existence of a direct intention. ${ }^{24}$ Otherwise, the insurer will be obliged to provide the performance, even if the event takes place in the period when the insurer's liability for suicide is excluded. It should be underlined, not without doubts, that the directionality of activity and not the directionality of fault is referred to. ${ }^{25}$ Moreover, it seems that not only sanity, but also the health, both physical and emotional, of the insured person, as well as the reason of the suicide are insignificant.

The same results from the insured person's death caused upon their consent, which happens especially in the case of euthanasia. ${ }^{26}$ It is irrelevant whether euthanasia was legal in the place where it was executed. ${ }^{27}$ Since suicide that does not constitute a prohibited act can release the insurer from the obligation to provide the payment to the insured person, legal euthanasia can exclude the insurer's liability. The German legal system excludes the insurer's payment obligation if the insured person's death resulted from illegal behaviour of the person entitled to the performance. The case is similar with a performance payable to a third party who indicated the insured person and then led to the death of the latter as a result of illegal activity. Then, the insurer's liability is excluded. ${ }^{28}$

What is important, the provision of Article 833 of the Civil Code refers to the effective suicidal attempt ending with the death of the insured. It does not stipulate the rules and conditions of the insurer's liability in the situation of attempting suicide that resulted only in bodily injury or health disturbance. Since upon a lapse of not more than 2 years suicide of the insured does not release from the obligation of providing the performance, the more so, upon a lapse of this period of time, other behaviour of the insured, such as a failed suicidal attempt or self-harm, should not release the insurer from the obligation of providing the performance. However, insurance companies often provide in the contents of the General Insurance Conditions for the exclusion of the insurer's liability not only in the case of the insured person's death as a result of suicide, an attempt to commit suicide or self-harm or

24 Ciepła, H., in: Bieniek, G. (ed.), Komentarz. Zobowiązania, Tom II, Legalis 2011, Article 833, par. No. 1.

25 It means that suicide also includes an attempt to take one's life by a mentally ill person, who cannot be blamed. As in: Orlicki, M., in: Gutowski, M. (ed.), Komentarz, Tom II, Legalis 2019, Article 833, par. No. 4. Otherwise: Krajewski, M., op. cit., par. No. 2. In his opinion, suicide only applies to persons of sound mind.

26 Kondek, J.M., in: Osajda, K., (ed.), op. cit., Legalis.

27 Orlicki, M., in: Gutowski, M. (ed.), op. cit., par. 4.

28 Section 162, Insurance Contract Act, op. cit. (accessed 1.02.2020). 
harming the insured upon their own request committed within 2 years of the date of concluding the agreement.

Considering the fact that between the activity and death of the insured person a certain period of time can pass, it should be asked which moment determines and is taken into consideration while calculating the 2-year period of time. It seems, however, that the 2-year period of time should be calculated from the insurance contract's conclusion until the day of the suicidal death, thus, the actual loss of life.

Irrespective of the above, provisions of the insurance contract or contents of the General Insurance Conditions (hereinafter: the General Insurance Conditions) can provide for the exclusion of the insurer's liability due to the character of the activity, among others, especially risky activity. Moreover, despite the explicit regulation under Article 833 of the Civil Code, insurers usually include in the General Insurance Conditions provisions stipulating for exclusion of liability in the case of the insured person's suicide.

The solution adopted by the national legislator was also expressed in the law binding in the territory of Canada. The Uniform Life Insurance Act provides for the claims of persons entitled to compensation with regard to the insured person taking their own life, whereas Quebec's legal system provides for a possibility of refusing to accept the liability for suicide if it is committed within 2 years as of the date of contract conclusion. ${ }^{29}$

Where it is deemed that the death did not result from a suicidal act, it can be considered as the insurance accident in the life insurance, which in turn obliges the insurer to pay. It has to be remembered that pursuant to Article 6 of the Civil Code, the insurer is obliged to prove that the insured committed suicide, that is, took deliberate actions in order to take their own life. Only by proving this premise would the insurer be released from the payment obligation and thus would construe legal consequences beneficial for him. ${ }^{30}$

As has already been mentioned, the insurer is not obliged to provide the insurance performance in case the insured commits suicide, unless the suicide is committed upon a lapse of the period of time after the insurance contract's conclusion specified by the legislator. Usually, this period is 2 years, but, it can be shortened in the contract or in the General Insurance Conditions, but not more than to 6 months. This period should be calculated as of the day of covering the insured with protection, which, as a rule, will correspond with the day of concluding the

29 Hołyst, B., Suicydologia, Warszawa 2012, p. 180.

30 Judgement of the District Court in Bydgoszcz of 5 November 2015, II Ca 268/15, http://orzeczenia. bydgoszcz.so.goVol.pl/content/\$N/151005000001003_II_Ca_000268_2015_Uz_2015-11-05_002 (accessed 15.02.2020). 
contract, yet, in the case of contracts concluded to the benefit of a third party, it can happen only upon the insured person's submission of the declaration of consent to coverage if the consent has been submitted upon conclusion of the insurance contract. In the case of contracts concluded to the benefit of a third party, changing the insurer does not interrupt the running of this 2-year period of time, which is justified with regard to the teleological interpretation. The lapse of this period of time causes that it is impossible to assume that the motive of concluding the insurance contract was the planned suicide and a possible change of the insurer, on which the insured person has no impact, does not change it. ${ }^{31}$

Although the provisions of the Civil Code regulating the insurance contract do not provide for, in isolation from the General Insurance Conditions, any specific premises of the insurer's liability in the scope of particular types, ${ }^{32}$ the provision of Article 833 of the Civil Code covers with its scope only the suicide of the person with life insurance. It does not apply in the case of a suicidal death of a person with personal accident insurance, since it cannot be considered as a personal accident. ${ }^{33}$ Therefore, the insurer is free from the liability under personal accident insurance also in the case the suicidal death of the insured which happened upon a lapse of two years from concluding the insurance contract.

Application of this provision is also excluded if the insurance event in the life insurance is an accident in the insured person's life consisting in changing their family situation as a result of death of their family member specified in the insurance contract (e.g. death of a child, a spouse, a parent, a sibling). For the existence and scope of the insurer's liability it is unimportant whether this death results from suicide, since in such a case the person who committed the suicide is not the insured. Nonetheless, the Act does not prohibit contractual exclusion of the insurer's liability, also when the suicidal death of the family member took place upon a lapse of 2 years from the insurance contract's conclusion.

However, one should remember that grace can also concern other events such as a serious disease, a surgery or a diagnosed tumour. Furthermore, the contents of

31 See: judgment of the Appellate Court in Poznań of 5 December 2017, I ACa 649/17, Legalis No. 1717466.

32 Judgement of the Supreme Court of 29 November 1982, I CR 407/82, Legalis No. 23458. However, it is underlined that the concept of damage in the insurance contract is the same as the concept of damage in other sections of the insurance law, yet, the characteristics of the insurance law causes modification of the principles of liability for damages, including, sometimes exclusion thereof. See: judgment of the Supreme Court of 19 May 2016, IV CSK 552/15, Legalis No. 1508609.

33 Kęszycka, B., in: Glicz, M. and Serwach, M. (eds.), Prawo ubezpieczeń gospodarczych. Komentarz. Tom II. Prawo o kontraktach $w$ ubezpieczeniach. Komentarz do przepisów $i$ wybranych wzorców umów, Warszawa 2010, p. 395. 
the General Insurance Conditions provide for the exclusion of the insurer's liability in the situation of driving a car under the influence of alcohol or other narcotic drugs, or staying in the territory of a country where acts of war take place.

\section{Information obligation}

Depression is a chronic disease ${ }^{34}$ and may constitute a reason for excluding persons suffering from it from the subjective scope of the life insurance contract. Surely this health condition will not remain unnoticed by the insurer. In the insurers' opinion, the mental condition of persons suffering from depression entails an increased risk of damage to health. Thus, it is necessary to verify the stability of the potential insured person's health condition, the number and type of medications they take and also the treatment stage..$^{35}$ Due to the role of diseases in the insurance contract's conclusion, it remains necessary to consider the impact of depression on the amount of the insurance premium and payment of the benefit, the relation between depression and suicidal death and finally, fulfilment of the information obligation by the policyholder.

Firstly, it should be noticed that the policyholder is obliged to inform the insurer of any known circumstances about which the insurer asked in the offer form or in other letters before concluding the contract (vide: Article 815 of the Civil Code). Thus, it should be considered whether the policyholder's hiding important information on their health, that is, the information on depression treatment, excludes the insurer's liability.

First of all, it should be underlined that using by the insurer the statutory sanction of releasing themselves from the provision of a performance is only possible when the insurer makes an enquiry referred to in Article 815 par. 1 first sentence of the Civil Code. It is impossible to state that it is sufficient for the insurer to solely have the information on the circumstances important from the point of view of the insurance risk, coming from, among others, their own findings, universally known information or the information given by the policyholder with regard to the conclusion of other insurance contracts or with regard to negotiations undertaken

34 See: the International Classification of Diseases ICD-10. https://www.cdc.gov/nchs/icd/icd10.htm (accessed 1.08.2020).

35 Insurers often refuse concluding a contract in the preliminary period of the treatment process due to the increased risk of, among others, suicide. See: Puto, M. op. cit., p. 21. 
by the parties. ${ }^{36}$ This obligation is, in fact, of directional and purposeful character, aimed at obtaining specific information and only then does it condition the sanction of releasing the insurer from providing the performance. ${ }^{37}$ Above all, the policyholder's obligation is limited to the circumstances known to them. Importantly, between the hidden circumstance and a specific insurance event there should be an adequate causal link, whereas the burden of proof that the circumstances given by the policyholder were not compliant with their knowledge is put on the insurer. ${ }^{38}$

Thus, the policyholder is not obliged to inform the insurer of all circumstances known to them, but only of the circumstances the insurer asked about before concluding the insurance contract. Not having asked about mental illnesses before concluding the contract, the insurer cannot refer to the nondisclosure of important circumstances and demand application of Article 815 par. 3 of the Civil Code.

It should be noted that in the case of personal insurance the legislator limits the possibility to refer to untrue information, especially nondisclosure of the insured person's disease if the accident happened three years after the life insurance contract's conclusion, whereas, the contract or the General Insurance Conditions can shorten this period of time (vide: Article 834 of the Civil Code).

While returning to the information obligation, the manner of formulating questions, which should not be imprecise, ambiguous, compound-complex and additionally, should not be misleading as a result of the improper use of conjunctions or alternatives, should be underlined. ${ }^{39}$ Negative consequences of improper formulation of a question should, however, lie with the insurer and not with the policyholder.

Secondly, undoubtedly, depression is among the aforementioned risk factors. It should be added that the so-called underwriting is necessary for the risk assessment. Estimation of the risk related to health is usually related to obtaining relevant information, including in the scope of the performed profession, or to undergoing

36 Judgement of the Administrative Court in Białystok of 18 March 2019, I ACa 696/18, Legalis No. 1978561.

37 Judgement of the Appellate Court in Rzeszów of 7 March 2017, I ACa 278/16, LEX No. 2630497; Rogowski, S., Granice zwolnienia ubezpieczyciela od odpowiedzialności. Naruszenie zasady obowiązu informowania przez ubezpieczajacego, "Przegląd Ubezpieczeń Społecznych i Gospodarczych" 1999 No. 10, p. 34 ff.; see: Tadla, A., Umowa ubezpieczenia na życie: zawieranie umowy, dochodzenie roszczeń, wzory, Warszawa 2000, p. 65.

38 Judgment of the Administrative Court in Białystok of 21 April 2015, I ACa 1039/14, Legalis No. 1249495.

39 Kamieński, W., Deklaracja ryzyka w umowie ubezpieczenia na życie, in: Szumlicz, T. (ed.), Problemy ochrony konsumenta na rynku ubezpieczeń, Warszawa 2006, p. 105; Puto, M., op. cit., pp. $15-16$. 
relevant examinations. Underwriting should, in principle, precede any insurance contract. On the one hand, it protects the insurer by allowing objective risk assessment; and on the other hand, it allows protection of the insured.

\section{Conclusions}

The ban on the insurer's referral to the suicidal death of the insured, if it happened 2 years after concluding the insurance contract, is justified with humanitarian reasons. The aim of the regulation is to prevent situations when the insured intending to take their own life abuses the legal relationship, that is, the contract of the highest trust. Therefore, the introduction of this term was aimed at not as much the protection of the insurer's interest, as the public interest. ${ }^{40}$

The compilation of regulations of the insurance contract on the one hand, and the dynamics of mental processes on the other, leads to the conclusion that suicidal thoughts that can lead to a suicidal death appear many times in minds of persons, who at the moment of concluding the insurance contract do not even allow the possibility of committing suicide or, the more so, do not show such symptoms. Such sudden change in opinion or the appearance and intensification of disease symptoms should not lead to excluding the insurer's liability.

The issue presented above has been noticed in the judicature. The Administrative Court in Warsaw stated that the insured person's depression was not the cause of the suicide with a reservation that it could have increased probability of committing it. A suicidal death does not, in fact, result from the circumstances not disclosed to the insurer, since it is a result of a conscious decision. At the moment of concluding the insurance contract it is difficult to expect from the insured that they foresee their future condition and the more so, their decision. ${ }^{41}$

Thus, while this regulation should not raise any doubts, indicating by the legislator such a rigid boundary (term) does not correlate with suicide, which is most often the last stage of an illness (among others, depression) and as a phenomenon is not made only of one act, a single activity of taking one's own life, but of many events and behaviours that in final result, lead thereto.

From the point of view of the potential insured suffering from a chronic disease, in the process of obtaining a desired insurance cover one can come across obstacles.

40 Fras, M., in: Habdas, M. and Fras, M. (eds.), op. cit., p. 391.

41 Judgment of the Administrative Court in Warszawa of 23 June 2015, VI ACa 859/14, http://orzeczenia.waw.sa.goVol.pl/content/\$N/154500000003003_VI_ACa_000859_2014_Uz_2015-0624_002 (accessed 1.02.2020). 
However, it seems that refusal to cover with insurance should happen only in exceptional situations, each time preceded with a detailed and diligent review of a given person's situation.

\section{References}

Ciepła, H., in: Bieniek, G. (ed.), Komentarz. Zobowiązania, Tom II, Legalis 2011.

Czabański, A. and Mariański, J., Samobójstwo w ujęciu Marii Janosz, "Teologia i Moralność" 2018, No. 2 (24).

Dubis, W., in: Gniewek, E. and Machnikowski, P. (eds.), Kodeks cywilny. Komentarz, Legalis 2019.

Durkheim, E., Samobójstwo. Studium z socjologii, translated by K. Wakar, Warszawa 2006.

Fras, M., in: Habdas, M. and Fras, M. (eds.), Kodeks cywilny. Komentarz. Tom V. Zobowiązania. Część szczególna (art. 765 - 92116), Warszawa 2019.

Gawlik, Z., in: Kidyba, A. (ed.), Kodeks cywilny. Komentarz, Tom III, Warszawa 2014.

Guzel-Szczepiórkowska, Z. and Visan, J., Ocena ryzyka w ubezpieczeniach życiowych, in: Doan, O. (ed.), Ubezpieczenia życiowe, Warszawa 1995.

Hołyst, B., Suicydologia, Warszawa 2012.

Hołyst, B., Wiktymologia, Warszawa 2000.

Kamieński, W., Deklaracja ryzyka w umowie ubezpieczenia na życie, in: Szumlicz, T. (ed.), Problemy ochrony konsumenta na rynku ubezpieczeń, Warszawa 2006.

Kasprzyk, R., Glosa do wyroku SA w Łodzi z 14 marca 1996 r., I ACr 62/96, "Palestra” 1997, No. 3-4.

Kęszycka, B., in: Glicz, M. and Serwach, M. (eds.), Prawo ubezpieczeń gospodarczych. Komentarz. Tom II. Prawo o kontraktach w ubezpieczeniach. Komentarz do przepisów i wybranych wzorców umów, Warszawa 2010.

Kondek, J.M., in: Osajda, K. (ed.), Kodeks cywilny. Komentarz, Legalis 2020.

Krajewski, M., Umowa ubezpieczenia. Art. 805 - 834 KC. Komentarz, Legalis 2016.

Lebiedowicz, A., Samobójstwo w ujęciu wielopłaszczyznowym, "Wojskowy Przegląd Prawniczy" 2013, No. 3, http://www.npw.internetdsl.pl/Dokumenty/2013-3/2013-3-5. pdf.

Manninger, K.A., Man against himself, New York 1938.

Orlicki, M., in: Gutowski, M. (ed.), Komentarz, Tom II, Legalis 2019.

Puto, M., Wykluczenie z ubezpieczenia nażycie osób dotkniętych określonymi chorobami przewlekłymi, "Wiadomości Ubezpieczeniowe" 2014, No. 2.

Rogowski, S., Granice zwolnienia ubezpieczyciela od odpowiedzialności. Naruszenie zasady obowiązku informowania przez ubezpieczającego, "Przegląd Ubezpieczeń Społecznych i Gospodarczych" 1999, No. 10. 
Szczepańska, M., Ubezpieczenie na życie z ubezpieczeniowym funduszem kapitałowym, Warszawa 2011.

Tadla, A., Umowa ubezpieczenia na życie, Warszawa 2000.

Tadla, A., Umowa ubezpieczenia na życie: zawieranie umowy, dochodzenie roszczeń, wzory, Warszawa 2000.

\section{CITATION}

Paleczna, A., Suicide as an insurance accident, "Acta Iuris Stetinensis" 2020, No. 3 (Vol. 31), 63-77, DOI: 10.18276/ais.2020.31-04. 